\title{
MODEL PEMBELAJARAN KOOPERATIF ING NGARSA SUNG TULADHA
}

\author{
Kartini Hutagaol ${ }^{1}$, Louise M. Saija ${ }^{2}$, Debora C. Simanjuntak ${ }^{3}$ \\ Dosen Fakultas Keguruan dan Ilmu Pendidikan \\ Universitas Advent Indonesia \\ 1kartinih_smant@yahoo.com, ${ }^{2}$ louise_saija@yahoo.com, ${ }^{3}$ deborachaterins @ gmail.com
}

\begin{abstract}
Abstrak: Dewasa ini sering dilihat pada tayangan televisi bahwa kerusakan moral lulusan bangsa sangat mencemaskan, tindakan korupsi (kasus suap), kenakalan remaja, tawuran antar pelajar dengan kekerasan fisik, bom bunuh diri yang brutal, dan anarkis. Dalam menyikapi kenyataan krisis moral, krisis karakter yang memprihatinkan yang dihadapi Bangsa Indonesia, Kurikulum 2013 sudah menekankan dan mengarahkan hakekat pendidikan kepada perbaikan sikap, yang merupakan hakekat pendidikan dalam konteks yang sesungguhnya, sebagaimana diyakini juga oleh Ki Hadjar Dewantara, menyangkut upaya dalam pembekalan semangat kebangsaan, semangat persaudaraan, mengayomi yang menerapkan nilai-nilai yang memberi keteladanan budi pekerti, untuk membentuk manusia yang bermoral, yang memiliki ketetapan pikiran (untuk berkomitmen) yang selaras dengan nilai-nilai sosial. Tim penulis melakukan suatu rancangan model pembelajaran kooperatif yang bernafaskan gagasan Ki Hadjar Dewantara, sebagaimana diungkapkan Soedjadi "apakah tidak mungkin dikembangkan model atau metode pembelajaran yang bertumpu pada falsafah kita sendiri? Selanjutnya Soedjadi berkata, "sekali lagi, bukan hal yang mustahil bahwa perkembangan baru tentang model pembelajaran di Indonesia, model itu kelak akan berpengaruh terhadap pembelajaran di Indonesia”. Untuk menyikapi ungkapan Soedjadi, tim penulis tertantang untuk merancang Model pembelajaran kooperatif Ing Ngarsa Sung Tuladha, sebagai jawaban dari pernyataan Soedjadi (1999, hal. 104) "Penulis merasa yakin bahwa sangatlah mungkin untuk mengkonstruksi model pembelajaran yang bernafaskan gagasan Ki Hadjar Dewantara." Dalam Riset tahap awal ini adalah melakukan studi empiris terhadap model pembelajaran yang dirancang untuk mengarahkan, menanamkan sikap dan budi pekerti di mana guru/dosen ditempatkan atau diposisikan sebagai pemimpin, yang akan memberi contoh atau tauladan yang baik secara kontinyu, memberi tauladan yang mulia kepada yang dipimpinnya. Semuanya itu betujuan untuk memantik jiwa para lulusan menjadi seorang pemimpin yang memiliki jiwa kebangsaan, persatuan, persaudaraan, tanpa membeda-bedakan suku, adat, dan agama, sehingga terhindar dari tindakan kekerasan dan anarkis. Penelitian studi empiris dalam proses berjalan, dilakukan pada pendidikan tinggi, SMA, SMP, SD yang ada di wilayah Jawa Barat. Populasi target pendidikan tinggi adalah mahasiswa Fakultas Ekonomi di Jawa Barat yang belajar Matematika Ekonomi, dan peserta didik SD, SMP, SMA di Jawa Barat. Dalam Penelitian empiris ini tahap pertama melibatkan 3 orang mahasiswa Prodi B. Inggris dan 3 orang mahasiswa Prodi Matematika. Dugaan sementara bahwa sikap, hasil belajar, kerja sama dalam satu tim, kemampuan dalam memimpin, kemampuan dalam memberi pertanyaan dan memberi jawaban atas pertanyaan dari peserta didik lebih baik daripada yang tidak menggunakan Model Pembelajaran Kooperatif Ing Ngarsa Sung Tuladha.
\end{abstract}

Kata Kunci: Model Pembelajaran Kooperatif Ing Ngarsa Sung Tuladha, Pemimpin yang Tuladha

Abstract: Today it is often seen on television shows that moral damage to national graduates is very worrying, acts of corruption (bribery cases), juvenile delinquency, brawls between students with physical violence, brutal suicide bombings, and anarchists. In responding to the reality of the moral crisis, the alarming character crisis faced by the Indonesian Nation, the 2013 Curriculum has emphasized and directed the nature of education to improve attitudes, which is the essence of education in the real context, as also believed by Ki Hadjar Dewantara, 
regarding the effort in debriefing the national spirit, the spirit of brotherhood, protecting those who apply values that exemplify manners, to form moral people, who have a mind set (to commit) that is in harmony with social values. The author team conducted a cooperative learning model design that inspired the idea of Ki Hadjar Dewantara, as revealed by Soedjadi "is it not possible to develop learning models or methods that rely on our own philosophy? Furthermore, Soedjadi said, "once again, it is not impossible that new developments about learning models in Indonesia, that model will affect learning in Indonesia." To address Soedjadi's expression, the writer's team was challenged to design Ing Ngarsa Sung Tuladha's cooperative learning model, in response to Soedjadi's statement (1999, p. 104) "The author feels confident that it is possible to construct a learning model that breathes the idea of Ki Hadjar Dewantara. This early stage research is conducting an empirical study of learning models designed to direct, instill attitudes and character in which the teacher / lecturer is placed or positioned as a leader, who will provide examples or good examples continuously, giving noble examples to those he leads. All of that aims to ignite the souls of the graduates to become leaders who have a nationality, unity, brotherhood, without discriminating ethnicity, customs, and religion, so as to avoid violence and anarchism. Empirical study research in the process of running, carried out in higher education, high school, junior high school, elementary school in the West Java region. The target population of tertiary education is students of the Faculty of Economics in West Java who study Mathematics Economics, and students of elementary, middle and high school in West Java. In this empirical research the first phase involved 3 students of English B. Study Program and 3 students of Mathematics Study Program. Provisional assumptions that attitudes, learning outcomes, teamwork, leadership ability, ability to ask questions and provide answers to questions from students are better than those who do not use Ing Ngarsa Sung Tuladha's Cooperative Learning Model. Keywords: Ing Cooperative Learning Model of Initiation of Sung Tuladha, Leader of the Tuladha

\section{PENDAHULUAN}

Dewasa ini sering dilihat pada tayangan televisi bahwa kerusakan moral lulusan bangsa sangat mencemaskan, baik birokrasi pemerintahan, aparat penegak hukum, bahkan di dunia pendidikan. Kerusakan moral bangsa nampak dengan tindakan korupsi, kenakalan remaja, tawuran antar pelajar dengan kekerasan fisik, bom bunuh diri yang brutal, dan anarkis. Jika hal ini dibiarkan, negara akan menuju ke arah kehancuran. Hal ini sejalan dengan pernyataan Natalia (2015) bahwa kerusakan moral bangsa sudah dalam tahap mencemaskan, baik secara birokrasi pemerintahan, aparat penegak hukum, bahkan di dunia pendidikan. Sedangkan Sutiyono menyatakan (dalam Suparlan, 2010) bahwa Bangsa Indonesia saat ini dihadapkan pada krisis karakter yang cukup memprihatinkan, seperti maraknya ketidakjujuran, kurangnya tanggung jawab sosial, hilangnya sikap ramah-tamah dan sopan santun. Selain hal tersebut di atas, abad ke 21 yang merupakan abad era globalisasi telah mengakibatkan pergeseran tujuan pendidikan nasional dari tingkat dasar sampai tingkat tinggi, yang sudah terfokus untuk menghasilkan lulusan yang menguasai ilmu. Dengan penguasaan ilmu dinilai mengarahkan peserta didik kepada hasil yang bersifat materialis, sebab peserta didik kurang dalam 
pembekalan semangat kebangsaan, semangat persaudaraan, dan semangat keadilan sosial, sikap dan moral, serta sifat-sifat kemanusiaan.

Dalam menyikapi kenyataan krisis moral, krisis karakter yang memprihatinkan yang dihadapi Bangsa Indonesia, Kurikulum 2013 dalam Permen Diknas 2016 telah menekankan dan mengarahkan hakekat pendidikan kepada perbaikan sikap, yang merupakan hakekat pendidikan dalam konteks yang sesungguhnya, sebagaimana diyakini juga oleh Ki Hadjar Dewantara, menyangkut upaya dalam pembekalan semangat kebangsaan, semangat persaudaraan, mengayomi yang menerapkan nilai-nilai yang memberi keteladanan budi pekerti, untuk membentuk manusia yang bermoral, yang memiliki ketetapan pikiran (untuk berkomitmen) yang selaras dengan nilai-nilai sosial.

Konsep pendidikan Ki Hadjar Dewantara kiranya dilakukan di sekolah secara berkelanjutan, dari tingkat dasar sampai tingkat tinggi, artinya para guru (Pemimpin) sebagai figur suri teladan yang menjiwai, melakoni Ing Ngarsa Sung Tuladha, akan menghasilkan lulusan yang tangguh. Lulusan sebagai manusia yang bermoral dalam kehidupan masyarakat, tidak menyalahgunakan kewenangan atau kekuasaan, tidak melakukan manipulasi keuangan, tidak melanggar kesusilaan, tidak brutal dan anarkis. Dalam pandangan pendidikan Ki Hajar Dewantara yang multiliterasi, dimana pendidikan multiliterasi yang memberikan kebebasan siswa dalam berpikir, berkreasi, dan berpendapat sejalan dengan konsep pancadarma, yang memiliki ciri yakni multi konsep, multi budaya, multi gaya belajar, dan multi multi modal memberikan sebuah konsep pendidikan yang memberikan kesan dan mengarahkan kepada nilai-nilai pancasila.

\section{Tujuan Khusus}

Bangsa Indonesia melalui generasi penerus bangsa perlu mewarisi dan merefleksikan kembali buah pemikiran Ki Hadjar Dewantara. Dalam pandangannya, tujuan pendidikan adalah memajukan bangsa secara menyeluruh tanpa membeda-bedakan agama, etnis, suku, budaya, adat, kebiasaan, status ekonomi, status sosial serta didasarkan kepada nilai-nilai kemerdekaan sejati. Abad ke 21 memberikan sebuah gambaran bahwa pendidikan menjadi semakin penting untuk menjamin peserta didik memiliki keterampilan belajar dan berinovasi, keterampilan menggunakan teknologi dan media informasi, serta dapat bekerja, dan bertahan dengan menggunakan keterampilan untuk hidup (life skills). Sejalan dengan pemaparan di atas, dengan merefleksikan kembali nilai pendidikan Ki Hajar Dewantara dalam perspektif pendidikan multiliterasi merupakan suatu wujud nyata dalam menyongsong pendidikan Indonesia agar kelak Indonesia mampu mewujudkan cita-citanya yakni menciptakan generasi emas 2045 (Susilo, 2018). Dengan ini, penulis merancang suatu Model Pembelajaran 
Kooperatif Ing Ngarsa Sung Tuladha. Model Pembelajaran Kooperatif Ing Ngarso Sung Tuladha boleh disebut dengan Model Pembelajaran Kooperatif Ing Ngarsa, dengan Pemimpin yang tauladan disebut dengan Tuladha. Model Pembelajaran Kooperatif Ing Ngarsa Sung Tuladha bertujuan: 1) Menekankan dan mengarahkan sikap, dan budi pekerti peserta didik. 2) Meningkatkan hasil belajar akademik. 3) Memantik rasa kegotong royongan, dan rasa kepemilikan dalam satu tim. 4) Melatih peserta didik untuk bertanya, dan menjawab pertanyaan serta melatih untuk memberikan alasan tentang jawaban yang diberikan peserta didik. 5) Melatih peserta didik menjadi seorang pemimpin yang tauladan. 6) Melatih dan mengarahkan pada penerimaan terhadap keragaman antar sesama peserta didik.

\section{Keutamaan Penelitian}

Penelitian ini penting untuk dilakukan mengingat bahwa tuntutan hidup abad ke-21 menuntut pendidikan mampu menghasilkan lulusan yang memiliki kompetensi hidup di abad ke-21, dan memasuki abad 21 kemajuan teknologi telah memasuki berbagai sendi kehidupan, termasuk pendidikan. Oleh sebab itu, perlu kiranya sebagai generasi penerus bangsa kembali membedah intisari dari konsep pendidikan menurut Ki Hajar Dewantara. Konsep pendidikan Ki Hadjar Dewantara kiranya dilakukan di sekolah secara berkelanjutan, dari tingkat dasar sampai tingkat tinggi, artinya para guru (Pemimpin) sebagai figur suri teladan yang menjiwai, melakoni Ing Ngarsa Sung Tuladha, akan menghasilkan lulusan yang tangguh. Untuk tujuan itu, perlu memantik jiwa para lulusan menjadi seorang pemimpin yang memiliki jiwa kebangsaan, persatuan, persaudaraan, tanpa membeda-bedakan suku, adat, dan agama, sehingga terhindar dari tindakan kekerasan dan anarkis. Dengan demikian guru/dosen ditempatkan atau diposisikan sebagai pemimpin, selalu melakukan contoh tauladan yang baik, contoh yang mulia kepada yang dipimpinnya. Gagasan pendidikan dengan prinsip pendidikan Ki Hadjar Dewantara, prinsip pemimpin (guru) yang Ing Ngarsa Sung Tuladha ditawarkan sebagai solusi yang akan dilakukan secara kontinyu, secara berkelanjutan. Kontinyu dengan alam masyarakat Indonesia sendiri, dilaksanakan secara konvergen dengan alam luar, dan akan bersatu dengan alam universal, dalam persatuan yang konsentris yaitu bersatu namun tetap mempunyai kepribadian sendiri, (Dewantara dalam Suparlan, 2016). Oleh sebab itu, perlu kiranya sebagai generasi penerus bangsa kembali membedah intisari dari konsep pendidikan menurut Ki Hajar Dewantara.

\section{KAJIAN PUSTAKA}

Ki Hadjar Dewantara memegang teguh tiga prinsip: Ing Ngarsa Sung Tuladha yang berarti guru sebagai pemimpin (pendidik) berdiri di depan dan harus mampu memberi teladan 
kepada anak didiknya. Ing Madya Mangun Karsa yang berarti bahwa seorang pemimpin (pendidik) berada di tengah harus mampu membangkitkan semangat anak didiknya. Tut Wuri Handayani yang berarti bahwa seorang pemimpin (pendidik berada di belakang, mengikuti dan mengarahkan anak didik agar berani berjalan di depan dan sanggup bertanggung jawab. Tim penulis ingin menggali prinsip yang pertama. yaitu prinsip Ing Ngarsa Sung Tuladha menjadi suatu model pembelajaran kooperatif, yang disebut sebagai: Model Pembelajaran Kooperatif Ing Ngarsa Sung Tuladha.

\section{Ing Ngarsa Sung Tuladha}

Ing Ngarsa Sung Tuladha artinya Ing ngarso itu di depan, Sung berasal dari kata Ingsun yang artinya "saya", Tuladha berarti tauladan. Jadi makna Ing Ngarsa Sun Tulado adalah menjadi seorang pemimpin (guru/pengajar) harus mampu memberikan suri tauladan bagi orang-orang disekitarnya. Figur seorang pemimpin (guru/pengajar) yang baik adalah menjadi suri tauladan atau panutan, (Syakhudin, 2012). Gagasan telah dilaksanakan di Taman Siswa yang memberi gambaran tentang fungsi seorang pendidik. Guru/pendidik ditempatkan atau diposisikan sebagai pemimpin, selalu melakukan contoh yang baik, contoh yang mulia kepada yang dipimpinnya. (Soedjadi, 1999). Guru yang berfungsi sebagai pemimpin yang Ing ngarsa Sung Tuladha, ia harus benar-benar siap dan tahu benar bahwa contoh informasi ataupun konsep yang disampaikan kepada anak didik adalah baik dan benar. Menyadari bahwa seorang pemimpin yang menentukan arah adalah panutan, maka sebagai panutan, kecenderungan bahwa orang yang ada disekitarnya akan mengikutinya. Seorang pemimpin harus mampu memberi suri tauladan berpegang teguh dengan tanggung jawabnya, selalu menyadari tindakannya, tingkah lakunya, cara berpikirnya, bahkan kebiasaaanya akan diikuti banyak orang.

Guru/pengajar berinteraksi langsung dalam proses belajar mengajar yang dapat merubah pola pikir atau karakter peserta didik. Bandura dalam Alfaiz, (2014) menjelaskan bahwa manusia belajar dari kehidupan sosialnya baik secara pengalaman aspek langsung (direct experience) ataupun pengalaman aspek tak langsung (vicarious experience) dan semua menjadi informasi yang kemudian diperoleh manusia dalam bentuk kemampuan kognitif dan diwujudkan dalam perilaku manusia di lingkungannya. Kedua aspek ini saling berinteraksi yang merubah pola pikir manusia, motivasi, afeksi dan tindakannya. Pengalaman langsung dari guru/pemimpin sebagai fasilitator menjadi contoh langsung yang ditiru digugu oleh peserta didik. Guru semestinya memiliki kurikulum tersendiri dalam mengarahkan, dan dalam mengembangkaan potensi setiap peserta didik, yaitu dengan memperlakukan dengan merangkul setiap anak sesuai dengan kemampuannya. Peserta didik tidak selalu mampu untuk 
mengembangkan potensinya sendiri tanpa bantuan orang lain, tetapi dengan kurikulum yang tersembunyi (cara yang berbeda-beda dalam memperlakukan setiap anak sesuai dengan kebutuhannya), pemimpin yang Ing Ngarso Sung Tuladha, siap menerima, siap merangkul peserta didiknya, dengan memberi contoh yang sesuai atau relevan dengan pengalaman setiap peserta didik.

Selain membangun kemampuan kognitif peserta didik, perlu membangun dan membentuk kemampuan afektif. Dalam membentuk kemampuan afektif peserta didik adalah dengan membentuk sikap dan akhlaknya. Kemampuan afektif tidak dipelajari sebagai layaknya pembelajaran untuk mengasah kemampuan kognitif dan psikomotor, melainkan butuh proses, salah satunya adalah dengan melalui aspek Ing Ngarsa Sung Tuladha dari guru/pemimpin sebagai pengajar langsung atau tidak langsung dalam pendidikan. Pendidikan afektif tidak bisa dipelajari dan dinilai dengan angka, tetapi melalui proses belajar dari lingkungan sosial. Pendidik haruslah menjadi model atau contoh yang akan diamati dan ditiru oleh peserta didik ketika berada dalam lingkungan kelas dan sekolah.

Belajar observasional merupakan salah satu pembelajaran yang tidak di atur secara tekstual, melainkan terjadi secara alami, dan merupakan salah satu cara dalam memberikan pembelajaran afektif. Ada beberapa variabel yang mempengaruhinya sehingga makin kuat efek proses belajar observasional ini bagi peserta didik yaitu: 1) Proses Atensional; Individu akan memperhatikan model yang dianggap efektif, atraktif, berkemampuan dibandingkan model yang lain, (Bandura: 1986). 2) Proses Retensional; Model yang diperhatikan memberikan informasi yang disimpan secara kognitif dan dapat dipanggil lagi ketika informasi itu diperlukan. Belajar observasional bertalian erat dengan kapabilitas peserta didik sesuai dengan keahliannya. Dengan demikian maka tugas guru sebagai pendidik Ing Ngarsa Sung Tuladha harus mampu memberikan pembelajaran yang efektif, mampu menampilkan secara kontinyu bagaimana cara yang beraklah mulia dan bersikap jujur, yang menjadi suri tauladan, karena guru/pemimpin sebagai model yang yang ditiru/digugu, diperhatikan dan menjadi sumber informasi bagi peserta didik.

Tugas guru/pemimpin Ing Ngarsa Sung Tuladha mampu memberikan pembelajaran yang efektif adalah bahwa tugas guru/pemimpin bukan hanya sekedar mengajar (teaching), tetapi lebih ditekankan pada membelajarkan (learning) dan mendidik. Arah pembelajaran seharusnya berfokus pada belajar, seperti: belajar memahami (learning to know), belajar melaksanakan (learning to do), belajar menjadi diri sendiri (learning to be), belajar hidup dalam kebersamaan yang damai dan harmonis (learning to live together in peace and harmony), (UNESCO dalam Hutagaol, 2010). Hal ini sejalan dengan pembelajaran yang efektif Snowball Throwing yang 
adalah paradikma pembelajaran efektif yang merupakan rekomendasi UNESCO yaitu: belajar mengetahui (learning to know), belajar bekerja (learning to do), belajar hidup bersama (learning to live to gether), dan belajar menjadi diri sendiri (learning to be), (Rijal, 2016).

Melalui proses learning to know, guru/pemimpin menggunakan kurikulum tersembunyi, sehingga setiap siswa diarahkan memahami fakta, konsep, ide, prinsip, hukum, teori, dan yang lainnya secara bermakna, baik hubungan antar ide dan alasan yang mendasarinya, dengan memunculkan pengetahuan yang lama dalam menerima ide, konsep (informasi) yang baru. Melalui proses leaning to do, siswa didorong belajar melaksanakan proses informasi yang diterimanya (doing) secara aktif untuk memacu peningkatan perkembangan intelektualnya. Melalui proses learning to be, siswa menghargai atau mempunyai apresiasi terhadap nilai-nilai dan keindahan akan produk dan proses suatu konsep tertentu, yang ditunjukkan dengan sikap senang, bekerja keras, ulet, sabar, disiplin, jujur, serta mempunyai motif berprestasi yang tinggi, dan rasa percaya diri. Melalui proses learning to live together in peace and harmony, siswa bersosialisasi dan berkomunikasi antar anggota kelompok maupun di luar anggota kelompok. Hal ini dilakukan melalui bekerja dan belajar bersama dalam kelompok kecil, menghargai pendapat orang lain, menerima pendapat yang berbeda, belajar mengemukakan pendapat atau bersedia sharing idea dengan orang lain dalam kegiatan belajar.

Ing Ngarsa Sung Tuladha adalah aspek kepemimpinan yang dimiliki pemimpin kelompok belajar. Aspek tersebut berkemampuan untuk menggerakkan dan mengarahkan anggota kelompok untuk menentukan arah dan tujuan belajar. Kepemimpinan adalah suatu proses yang mempengaruhi aktivitas kelompok yang diatur untuk mencapai tujuan bersama. Samko dan Yasumi (2010) mengungkapkan bahwa pemimpin kelompok belajar, memiliki keiklasan bekerja, memiliki kemahiran menjalin komunikasi yang benar. Juga memiliki kesanggupan untuk membangun suatu dialog dalam kelompok belajar, untuk memantik dan mengungkapkan gagasan di antara anggota kelompok tentang suatu topik tertentu, sehingga yang terjadi adalah pengetahuan tidak ditanamkan secara paksa tetapi ditemukan bersama oleh peserta kelompok. Salah satu aspek yang tidak kalah pentingnya dalam kepemimpinan Ing Ngarsa Sung Tuladha, yang juga merupakan kurikulum tersembunyi adalah mimik (raut) wajah selalu berbanding lurus dengan gerakan tangan. Dalam hal ini, dibutuhkan senyuman dan meminimalis penggunaan jari telunjuk, sebaiknya dapat menggunakan jari jempol atau dengan menggerakkan tangan dengan telapak tangan terbuka ke atas.

\section{Model Pembelajaran Kooperatif (Cooperative Learning)}

Model pembelajaran kooperatif (cooperative learning) adalah sekumpulan cara pengajaran yang dirancang untuk mendidik kerja sama kelompok dan interaksi antar siswa. 
Tujuan pembelajaran kooperatif minimal meliputi tiga tujuan pembelajaran, yaitu hasil belajar akademik, penerimaan terhadap keragaman, dan pengembangan keterampilan sosial, (Ibrahim dkk, 2000). Lie dalam Rijal (2016) menyebutkan cooperative learning dengan istilah pembelajaran gotong royong, di mana sistem pembelajaran memberi kesempatan kepada peserta didik, untuk belajar bekerja sama dengan siswa lain dalam tugas-tugas yang sudah terstruktur. Pembelajaran kooperatif akan berjalan kalau sudah terbentuk suatu kelompok atau suatu tim. Dalam pembelajaran kooperatif di dalamnya siswa akan belajar secara terarah dalam kelompok untuk mencapai tujuan yang sudah ditentukan dengan jumlah anggota kelompok yang terdiri dari 4-6 orang. Sedangkan menurut Slavin, cooperative learning adalah pembelajaran yang dilakukan secara berkelompok, siswa dalam satu kelas yang setting kelompok-kelompok kecil dengan memperhatikan keberagaman anggota kelompok sebagai wadah bekerja sama dan memecahkan suatu masalah melalui interaksi sosial dengan teman sebaya, memberikan kesempatan pada peserta didik untuk mempelajari sesuatu dengan baik pada waktu yang bersamaan dan ia menjadi nara sumber bagi teman yang lain.

Model Pembelajaran Kooperatif dirancang berlandaskan pada teori belajar konstruktivisme Vygotsky, yang menekankan pada interaksi sosial sebagai sebuah mekanisme untuk mendukung perkembangan kognitif. Selain itu, model ini juga didukung oleh teori belajar bermakna David Ausubel, Teori kognitif belajar Jean Piaget, Teori belajar Jerome Bruner. Dalam rancangannya model pembelajaran kooperatif ini membantu peserta didik untuk lebih mudah menerima informasi yang diperoleh, karena proses informasi atau konsep akan didukung dengan adanya interaksi yang terjadi dalam Pembelajaran Kooperatif.

Pembelajaran kooperatif relevan dalam pendidikan di Indonesia, dengan istilah pembelajaran gotong royong, di mana sistem pembelajaran memberi kesempatan kepada peserta didik, untuk belajar bekerja sama dengan siswa lain dalam tugas-tugas yang sudah terstruktur. Pembelajaran kooperatif bukan hal yang baru atau secara lebih umum, di dunia (Gillies, 2016). Sejak pertama kali diimplementasikan dan kemudian dilaporkan pada tahun 1980an sampai dengan sekarang, pembelajaran kooperatif memberikan manfaat yang besar dalam mengurangi kesenjangan antar siswa yang pandai dan kurang pandai (Saija, 2010). Roseth et al. dan Johnson \& Johnson (2008) sebagaimana dilaporkan oleh Gillies (2016), dari meta analisys terhadap 148 penelitian, hasil belajar siswa sekolah menengah (adolescents) dan hubungan teman sebaya menjadi lebih baik pada pembelajaran kooperatif, jika dibandingkan dengan pembelajaran individu yang sifatnya kompetitif. Sementara Duren dan Cherrington (Hutagaol, 2007) menyatakan bahwa terdapat perbedaan yang signifikan pada ingatan jangka panjang (students long-term retention) antara siswa yang belajarnya mengerjakan latihan 
secara kelompok dibandingkan dengan siswa yang bekerja secara sendiri. Dengan cara memberikan soal yang sama kepada dua kelompok siswa tersebut, beberapa bulan setelah proses pembelajaran, diperoleh bahwa siswa yang dalam belajarnya bekerja dalam kelompok kecil, ternyata lebih mampu menguasai materi pelajaran dibandingkan dengan siswa yang dalam belajarnya bekerja secara individu.

Belajar dalam kelompok kecil dengan maksud agar semua peserta didik terlibat secara aktif dalam proses pembelajaran, (MKPBM, 2001). Siswa dibagi dalam kelompok-kelompok kecil untuk saling bekerja sama dalam menyelesaikan suatu permasalahan atau suatu tugas untuk mencapai tujuan bersama. Pada setiap kelompok terdapat siswa yang pandai yang dapat membimbing atau membantu siswa lain yang berkemampuan kurang, sehingga dapat terjadi kolaborasi antar siswa maupun antar kelompok. Dengan pembelajaran kooperatif siswa berlatih menghargai dan mendengar pendapat anggota kelompok, saling mendukung demi keberhasilan setiap kelompok. Juga saling membantu dalam membangun pengetahuan baru dengan mengintegrasikan pengetahuan lama masing-masing individu. Dengan demikian diharapkan dapat menerapkan nilai-nilai kerja sama dalam kehidupan sehari-hari.

Namun pada kenyataannya, pada saat pembelajaran kooperatif diimplementasikan dan siswa diminta belajar bersama kelompoknya, banyak siswa dalam kelompok yang tidak bekerjasama dan mengharapkan temannya saja yang bekerja atau sebagian siswa yang merasa pembelajaran kooperatif sebagai saat untuk berpesta. Sedangkan banyak guru yang tidak dapat mengendalikan pembelajaran berjalan dengan baik dan pembelajaran kooperatif menjadi berantakan (Slavin, 2014). Hal tersebut disebabkan minimnya perhatian terhadap prinsip pembelajaran kooperatif di mana setiap kelompok harus dibentuk dengan anggota-anggota yang bertanggung jawab dan yang merasa saling bergantung sama lain untuk mencapai tujuan yang sama. Efe and Efe (2011) menambahkan bahwa perlu dipilih pemimpin untuk setiap kelompok karena dalam penelitiannya ditemukan bahwa pemimpin kelompok mempengaruhi motivasi anggota kelompok lainnya dalam berbagai cara. Hal itu berarti peran pemimpin kelompok sama pentingnya dengan peran guru, yaitu sebagai fasilitator.

Pemimpin kelompok yang dimaksud adalah pemimpin yang memiliki kemampuan komunikasi yang baik, dan selain memiliki kemampuan kognitif semestinya memiliki kemampuan afektif yang baik, sehingga kemampuan sosialnya bagus yang yang dapat mempengaruhi keberhasilan setiap kelompok. Dengan kataan lain, bahwa pemimpin kelompok harus dipilih sedemikian agar pembelajaran kooperatif dapat berhasil sesuai dengan rencana yang diharapkan. Model pembelajaran kooperatif yang memiliki pemimpin kelompok adalah model pembelajaran kooperatif Snowball Throwing. Setiap kelompok belajar yang diwakili 
ketua atau pemimpin kelompok untuk mendapat tugas dari guru, kemudian masing-masing siswa membuat pertanyaan yang dibentuk seperti bola (kertas pertanyaan) lalu dilempar ke siswa lain yang masing-masing siswa menjawab pertanyaan dari bola yang diperoleh. Dalam rancangan ini tim penulis merancang model pembelajaran kooperatif Ing Ngarsa Sung Tuladha, yang relevan dengan model pembelajaran kooperatif Snowball Throwing.

\section{Model Pembelajaran Kooperatif Ing Ngarsa Sung Tuladha}

Soedjadi dalam buku Kiat Pendidikan Matematika di Indonesia menuliskan dan mempertanyatan "apakah tidak mungkin dikembangkan model atau metode pembelajaran yang bertumpu pada falsafah kita sendiri? Selanjutnya beliau berkata, sekali lagi, bukan hal yang mustahil bahwa perkembangan baru tentang model pembelajaran di Indonesia, model itu kelak akan berpengaruh terhadap pembelajaran di Indonesia. Model pembelajaran kooperatif Ing Ngarsa Sung Tuladha, boleh dipertimbang merupakan jawaban dari pernyataan Soedjadi (1999, hal. 104) "Penulis merasa yakin bahwa sangatlah mungkin untuk mengkonstruksi model pembelajaran yang bernafaskan gagasan Ki Hadjar Dewantara.”

Menurut Ki Hadjar Dewantara bahwa para guru/pemimpin hendaknya menjadi pribadi yang bermutu dalam kepribadian dan kerohanian, baru kemudian menyediakan diri untuk menjadi pahlawan dan juga menyiapkan para peserta didik untuk menjadi pembela nusa dan bangsa. Artinya bahwa yang diutamakan sebagai pendidik pertama-tama adalah fungsinya sebagai model atau figur keteladanan, baru kemudian sebagai fasilitator atau pengajar, (Riyanto, 2008). Sang Hajar atau pengajar (pemimpin) adalah seseorang yang memiliki kelebihan selain ranah kognitif dan psikomotor, semestinya memiliki kemampuan yang tinggi dalam ranah afektif. Keberhasilan pembelajaran pada ranah kognitif dan psikomotor dipengaruhi oleh kondisi afektif peserta didik. Untuk mencapai hasil belajar yang optimal, dipertimbangkan merancang model pembelajaran dalam kegiatan pembelajaran bagi peserta didik yaitu Model pembelajaran kooperatif Ing Ngarsa Sung Tuladha, model pembelajaran kooperatif yang memperhatikan karakteristik, kognitif, psikomotor, terutama pada asfek afektif dari guru/pemimpin maupun peserta didik.

Model pembelajaran kooperatif Ing Ngarsa Sung Tuladha merupakan pengembangan dari model kooperatif Snowball Throwing. Model ini memiliki suatu cara penyajian bahan pelajaran, di mana siswa dibentuk dalam beberapa kelompok belajar yang heterogen yang mengarahkan peserta didik mencapai tujuan pembelajaran bersifat kerja sama dalam kelompok kecil. Kerja sama diharapkan akan terjadi antara pemimpin kelompok dengan anggota kelompok, dan antara setiap anggota kelompok, sehingga terjadi komunikasi multi arah. Setiap kelompok belajar dalam model pembelajaran kooperatif Ing Ngarsa Sung Tuladha harus 
memiliki seorang pemimpin kelompok yang akan mendapat arahan dan tugas dari guru. Pemilihan pemimpin kelompok dalam model pembelajaran kooperatif Ing Ngarsa Sung Tuladha ini, tidak lepas dari ranah afektif.

Ketua kelompok atau pemimpin disebut Tuladha. Penentuan/penyaringan TuladhaTuladha, dilakukan guru dengan membagikan lembar isian instrumen penilaian kreatif kognitif dan lembar isian instrument penilaian afektif yang meliputi lembar pengamatan sikap. Pemilihan ini dilakukan sebelum diberikan treatment terhadap peserta didik. Peserta didik yang memperoleh nilai yang tertinggi akan terpilih sebagai Tuladha.

Guru sebagai Tuladha utama, terlebih dahulu menyampaikan konsep/informasi tentang materi pembelajaran. Tuladha utama menjelaskan kembali materi atau contoh-contoh yang sudah disampaikan kepada Tuladha-Tuladha. Tuladha kembali kepada anggota kelompoknya berperan sebagai fasilitator, mengarahkan dan membantu anggota kelompok belajar dalam menyatukan pendapat, ide dan gagasan kreatif dalam menyelesaikan permasalahan. TuladhaTuladha menggiring jalannya kelompok belajar dengan mengatur anggota secara bergantian untuk menuliskan pertanyaan, dan menentukan siapa anggota kelompok yang akan memberikan jawaban. Tuladha utama selalu siaga memperhatikan proses pembelajaran setiap kelompok-kelompok belajar. Apabila Tuladha-Tuladha belum mengerti (memahami) pertanyaan dari anggota kelompok belajar maka Tuladha-Tuladha akan bertanya kepada Tuladha utama. Tuladha-Tuladha berperan aktif untuk menyampaikan dan menjelaskan kembali konsep/informasi tentang materi yang sudah diterimanya kepada anggota kelompoknya. Setiap anggota kelompok belajar, secara bergiliran diarahkan dengan sikap dan tutur kata yang baik dalam menuliskan pertanyaan, baik dalam memberi jawaban atas pertanyaan yang diberikan kepadanya. Setiap anggota kelompok belajar, digiring dengan penuh disiplin bergiliran untuk saling bertukar pikiran, saling bertanya dan menjawab sehingga setiap anggota dan Tuladha dapat mengerti permasalahan yang dihadapi. Setiap anggota kelompok belajar akan mampu mencari solusi suatu permasalahan yang dihadapi, dapat mengaitkan antar konsep atau antar topik yang dipelajari, dapat menyampaikan ide-ide atau konsep kepada anggota lain tentang materi pembelajaran, dapat mengemukakan ide-ide kreatif dan logis, dapat memberikan alasan terhadap pertanyaan kenapa-mengapa, dan dapat mempresentasikan ide-ide yang praktis dan kreatif ke sesama anggota kelompok belajar.

Setiap anggota kelompok belajar bangga dengan prestasi kelompoknya, sehingga mengedepankan kepentingan kelompoknya. Setiap anggota kelompok yang mampu membantu dalam memberikan ide jawaban logis dan fraktis mendapat penghargaan, dan sebaliknya setiap anggota kelompok yang memiliki pertanyaaan yang logis menerima penghargaan, dalam hal 
ini penghargaan yang dimaksud disesuaikan dengan pertimbangan Tuladha utama. Dalam proses kegiatan pembelajaran, dihindari menggunakan jari telunjuk diganti dengan menggunakan jari jempol, atau menggunakan tangan dengan telapak tangan terbuka ke atas. Hal ini dimaksud untuk selalu menunjukkan ciri Tuladha yang menyentuh aspek afektif.

Model pembelajaran kooperatif Ing Ngarsa Sung Tuladha memiliki suatu cara penyajian bahan pelajaran, di mana siswa dibentuk dalam beberapa kelompok yang heterogen, kemudian setiap kelompok belajar sudah ditentukan pemimpin kelompok yang mendapat tugas dari guru. Pemilihan ketua kelompok dalam model pembelajaran kooperatif Ing Ngarsa Sung Tuladha, memenuhi aspek kognitif, afektif dan psikomotor. Pemimpin atau ketua kelompok disebut Tuladha. Sebelum dilakukan treatment, semestinya sudah ditentukan pemimpin kelompok (Tuladha) dalam hal ini diperlukan angket dan soal kreatifitas kognitif seperti terlampir pada hal 101.

Ciri khas model pembelajaran Kooperatif Ing Ngarso Sung Tulodo adalah mengutamakan kepemimpinan kelompok belajar yang Tuladha. Mengedepankan sikap dan tutur kata yang baik, dalam hal ini dibutuhkan senyuman dan meminimalis penggunaan jari telunjuk, sebaiknya dapat menggunakan jari jempol atau dengan menggerakkan tangan dengan telapak tangan terbuka ke atas, untuk mengikat dan membentuk sikap hormat terhadap sesama anggota kelompok belajar, menanamkan sikap penerimaan antar sesama, sehingga setiap anggota kelompok merasakan kepemilikan dalam satu tim, setiap anggota kelompok belajar bangga dengan prestasi kelompoknya, sehingga mempermudah mengarahkan setiap anggota kelompok untuk turut berperan aktif.

Berikut ini adalah sikap yang hendak bertumbuh pada diri peserta didik berdasarkan model pembelajaran Ing Ngarso Sung Tulodo: 1) Kejujuran atau moral yaitu perilaku yang didasarkan pada upaya menjadikan dirinya sebagai orang yang selalu dapat dipercaya dalam perkataan, tindakan (perbuatan), dan pekerjaan. 2) Disiplin yaitu tindakan yang menunjukkan perilaku tertib dan patuh pada berbagai ketentuan dan peraturan. 3) Kerja keras yaitu perilaku yang menunjukkan upaya sungguhsungguh dalam mengatasi berbagai hambatan belajar dan tugas, serta menyelesaikan tugas dengan sebaikbaiknya. 4) Kreatif yaitu berpikir dan melakukan sesuatu untuk menghasilkan cara atau hasil baru dari sesuatu yang telah dimiliki. 5) Mandiri yaitu sikap dan perilaku yang tidak mudah tergantung pada orang lain dalam menyelesaikan tugas-tugas. 6) Rasa ingin tahu yaitu sikap dan tindakan yang selalu berupaya untuk mengetahui lebih mendalam dan meluas dari sesuatu yang dipelajarinya, dilihat, dan didengar. 7) Peduli lingkungan yaitu sikap dan tindakan yang selalu berupaya mencegah kerusakan pada lingkungan alam di sekitarnya, dan mengembangkan upaya-upaya untuk 
memperbaiki kerusakan alam yang sudah terjadi. 8) Tanggung jawab yaitu sikap dan perilaku seseorang untuk melaksanakan tugas dan kewajibannya, yang seharusnya dia lakukan, terhadap diri sendiri, masyarakat, lingkungan (alam, sosial dan budaya), negara dan Tuhan Yang Maha Esa. 9) Demokratis yaitu Cara berfikir, bersikap, dan bertindak yang menilai sama hak dan kewajiban dirinya dan orang lain.

\section{Angket Penetuan Pemimpin (Tuladha)}

Untuk menentukakan pemimpin (Tuladha) disediakan berupa contoh lembar isian angket (boleh juga diganti sesuai dengan indikatornya) dan lembar isian soal kreatif kognitif sebagai berikut:

\section{ANGKET PENENTUAN PEMIMPIN (TULADHA)}

\section{Petunjuk Pengisian:}

1. Dimohon mengisi bagian A yaitu identitas responden.

2. Pada bagian B anda akan diminta untuk menjawab setiap pernyataan dengan memberikan tanda silang $(\checkmark)$ pada kolom yang paling tepat dan sesuai dengan keadaan yang sebenarnya. Berikut adalah kriteria skala penilaian

Skala penilaian positif

Sangat Setuju : :

Setuju : :

Tidak Setuju :

Sangat Tidak Setuju $\quad: 1 \quad$ Sangat Tidak Setuju $: 4$

Skala penilaian negatif

$: 4 \quad$ Sangat Setuju : 1

3 Setuju :2

2 Tidak setuju :3

\section{Bagian A. Identitas Responden}

\begin{tabular}{|l|l|}
\hline NAMA & \\
\hline UMUR & \\
\hline JENIS KELAMIN & \\
\hline
\end{tabular}

\section{Bagian B. Perspektif Siswa}

ANGKET PENILAIAN AFEKTIF

\begin{tabular}{|c|c|c|c|c|c|}
\hline \multirow[t]{2}{*}{ No. } & \multirow[t]{2}{*}{ Pernyataan } & \multicolumn{4}{|c|}{ Skala Penilaian } \\
\hline & & 4 & 3 & 2 & 1 \\
\hline \multicolumn{6}{|c|}{ Moral } \\
\hline 1. & $\begin{array}{l}\text { Bila saya berjanji pada orangtua, saya harus berusaha } \\
\text { menepatinya. }\end{array}$ & & & & \\
\hline 2. & Bila berjanji pada anak kecil, saya tidak harus menepatinya. & & & & \\
\hline \multicolumn{6}{|c|}{ Disiplin } \\
\hline 3. & $\begin{array}{l}\text { Pada saat ada jam kosong, karena guru tidak dapat hadir, maka } \\
\text { saya dan teman-teman segera meninggalkan kelas. }\end{array}$ & & & & \\
\hline 4. & Saya selalu berusaha hadir tepat waktu dalam setiap kegiatan. & & & & \\
\hline
\end{tabular}




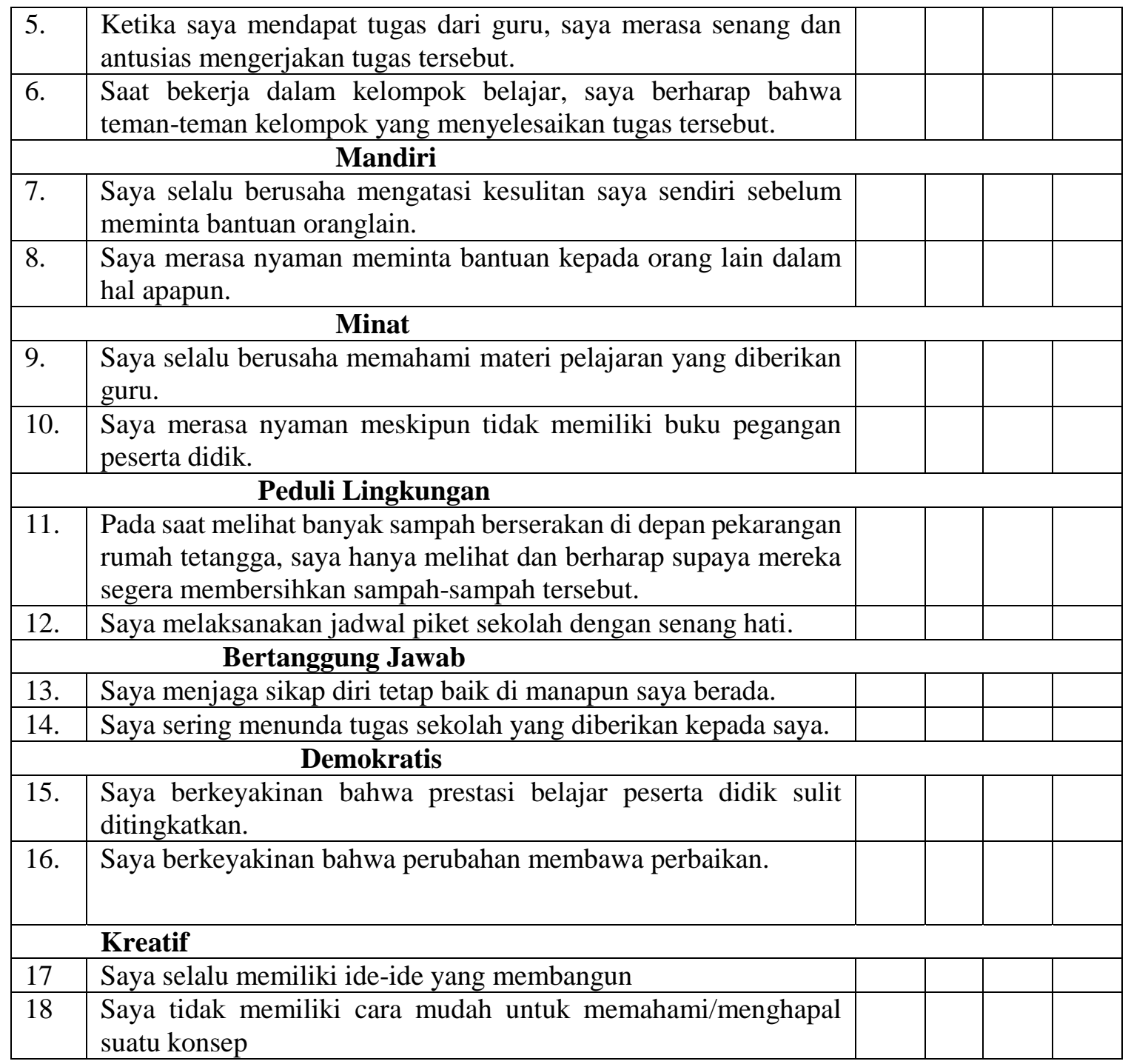

\section{Instrumen Kreatif Kognitif}

Selain lembar isian aspek afektif diberikan juga lembaran isian menyangkut kemampuan kreatif kognitif, supaya dalam penyaringan Tuladha-Tuladha tersebut semakin lebih lengkap dan lebih baik. Adapun lembar isian kreatif kognitif adalah sebagai berikut:

1. Dheo dan Theo melakukan perjalanan menyusuri hutan, mereka berhenti ketika melihat jurang yang lebarnya kira-kira $5 \mathrm{~m}$ dengan kedalaman $10 \mathrm{~m}$. Mereka harus menyeberangi jurang tersebut. Peralatan yang mereka miliki adalah tangga yang panjangnya $3 \mathrm{~m}$, tongkat kayu 2 potong masing-masing berukuran $3 \mathrm{~m}$, korek api, kawat, lilin 2 buah, tang dan tali dengan panjang tak terbatas. Uraikanlah jawabanmu tentang bagaimana mereka dapat menyeberang jurang tersebut?

Alternatif Jawaban Kreatif: 
Menjatuhkan tali yang panjangnya tidak terbatas ke dalam jurang, sehingga jurang akan tertutupi dengan tali dan rata dengan permukaan tanah, dengan demikian anak-anak dapat menyeberangi jurang dengan tenang, tanpa kawatir akan terjatuh ke dalam jurang.

2. Sekelompok anak anggota pramuka sedang menunggu anggota kelompok yang lain di lapangan parkir. Sambil menunggu anggota yang lain, enam orang anak dari kelompok tersebut bermain bola pingpong. Ketika sedang bermain, tanpa disengaja bola masuk ke dalam sebuah pipa baja yang tertanam dalam beton lapangan setinggi $75 \mathrm{~cm}$. Diameter pipa baja sedikit lebih besar dari diameter bola pingpong. Peralatan yang masing-masing miliki adalah segulungan kecil tali pramuka, gulungan potongan kawat jemuran sepanjang $10 \mathrm{dm}$, sebuah palu, sebuah tongkat, sebuah tang, sekotak cereal gandum, dan sebuah kunci inggris, satu bungkus nasi Padang, 3 cup air mineral, sekotak kecil kertas tisue. Uraikanlah jawabanmu tentang bagaimana cara ke-enam anak tersebut mengeluarkan bola dari dalam pipa.

Alternatif Jawaban Kreatif:

Bentuk pasta dari bahan cereal gandum, pasta tersebut taruh di atas tisue, luruskan gulungan potongan kawat jemuran, bentuk pengait di bagian ujung yang satu, selanjutnya pasta tersebut tempelkan ke kawat pengait, tunggu sebentar sampai kira-kira bolanya uda nempel ke pasta, lalu bolanya boleh ditarik.

Luruskan potongan kawat, salah satu ujungnya bentuk melingkar, kemudian tuangkan sedikit air mineral, lalu tarik dengan potongan kawat.

3. Terdapat dua buah patok (tiang) yang berdiri tegak dengan masing-masing tingginya 300 $\mathrm{cm}$. Sebuah tali dengan panjang $500 \mathrm{~cm}$ diregangkan dari satu ujung patok ke ujung patok yang lain, dan digantungkan dengan bebas di antara kedua patok tersebut. Titik terendah tali tersebut adalah $50 \mathrm{~cm}$ di atas permukaan tanah. Buatlah gambar (model) dari soal cerita ini, dan berapakah jarak kedua patok tersebut?

Alternatif Jawaban Kreatif: Patoknya rapat, tidak ada jarak, sebab jika tali dibagi dua panjangnya $250 \mathrm{~cm}$, dan jarak tali ke permukaan tanah adalah $50 \mathrm{~cm}$, berarti kedua tiang rapat.

(Adobsi: Solso, et al (2008). Cognitive Psychology)

\section{METODE PENELITIAN}

Penelitian ini menggunakan metode deskripisi dan metode eksperimen. Metode eksperimen dilakukan untuk mendukung hasil studi empiris. Dalam studi empiris, dan merupakan rencana yang sedang berjalan melibatkan 3 orang mahasiswa Prodi Pendidikan 
Matematika sebagai peneliti dan 3 orang mahasiswa Prodi Pendidikan Bahasa Inggris. Peneliti menggunakan Model Pembelajaran Kooperatif Ing Ngarsa Sung Tuladha sebagai sala satu treatment dan dibandingkan terhadap model yang lain. Tahapan berikutnya yang akan dilakukan adalah studi konfrehensip, apakah dapat menerapkan Model Pembelajaran Kooperatif Ing Ngarsa Sung Tuladha sebagai suatu model pembelajaran? Dugaan sementara: Model Pembelajaran Kooperatif Ing Ngarsa Sung Tulodo dapat meningkatkan: sikap dan budi pekerti, hasil belajar, kerja sama dalam satu tim, kemampuan dalam memimpin tim, kemampuan siswa dalam membuat pertanyaan dan memberi jawaban atas pertanyaan, dan dipertimbangkan menjadi satu model pembelajaran kooperatif.

Model Pembelajaran Kooperatif Ing Ngarsa Sung Tuladha sesuai dengan unsur budaya dan unsur sosial bangsa Indonesia. Hasil studi empiris sangat penting untuk mendukung penerapan Model Pembelajaran Kooperatif Ing Ngarsa Sung Tuladha. Penelitian empiris dilakukan pada pendidikan tinggi, SMA, SMP, SD yang ada di wilayah Jawa Barat, dengan waktu penelitian sedang proses berjalan. Populasi target pendidikan tinggi adalah mahasiswa Fakultas Ekonomi di Jawa Barat yang belajar Matematika Ekonomi, dan peserta didik SD, SMP, SMA di Jawa Barat.

\section{DAFTAR PUSTAKA}

Alfaiz. (2014) Pembelajaran Afektif Merupakan Salah Satu Strategi Dalam Pembentukan Karakter Peserta Didik (Sebuah Tinjauan dari Perspektif Psikologi; Social Cognitive Theory). Jurnal Pelangi. Vol.7, No.1, Hal 85-96

Bandura, A,1986. Social foundations of thought and action. Englewood Cliffs, NJ: Prentice Hall.

Efe, R., \& Efe, H. A., (2011) Using Student Group Leaders to Motivate Students in Cooperative Learning Methods in Crowded Classrooms. Educational Research and Reviews. Vol.6, No.2, Hal 187-196.

Gillies, R. (2016). Cooperative Learning: Review of Research and Practice. Australian Journal of Teacher Education Psychology, 41, 39-51.

Hutagaol, K. (2007). Pembelajaran Matematika Kontekstual untuk Meningkatkan Kemampuan Representasi Matematis Siswa Sekolah Menengah Pertama. Tesis. Bandung: UPI

Hutagaol, K. (2010). Strategi Multi Representasi Dalam Kelompok Kecil untuk Meningkatkan Kemampuan Pemecahan masalah Dan kemampuan Komunikasi Matematis Siswa Sekolah menengah Pertama. Disertasi. Bandung: UPI

Johnson, D. W., \& Johnson, R. T. (2008). Social independence theory and cooperative learning: The teacher's role. In R.B. Gillies, A.F. Ashman, \& J. Terwel (Eds.), The teacher's role in implementing cooperative learning in the classroom (pp. 9-37). New York: Springer.

Natalia, I. G. A. K. (2015). Implementasi Pandangan Ki Hajar Dewntara pada Pembelajaran Matematika. Proceeding Seminar Nasional. FMIPA UNDIKSHA V tahun 2015.

Rijal. (2016). Pengertian Model Snowball Throwing. Blog Berbagi Ilmu. Online https://www.rijal09.com/2016/05/pengertian-model-snowball throwing.html diakses 30 Agustus 2018. 
Saija, L. M. (2010). Pembelajaran berbasis Masalah dengan Model Kooperatif MURDER untuk Meningkatkan Kemampuan Pemecahan Masalah Matematis Siswa SMA. (Studi Eksperimen pada Siswa SMA Kelas XI IPA Lembang, Bandung). Tesis. Bandung: UPI.

Samho, B., Yasunari, O. (2009) Konsep Pendidikan Kihajar Dewantara dan Tantangan-tantangan Implementasinya di Indonesia Dewasa Ini. Lembaga Penelitian dan Pengabdian Kepada Masyarakat. Repository Universitas Katolik Parahyangan.

Slavin, R. (2014). Cooperative learning and academic achievement: Why does group work? Anales De Psicologia, 30, 785-791.

Soedjadi.1999/2000, Kiat Pendidikan Matematika di Indonesia, Jakarta: Direktorat Jenderal Pendidikan Tinggi Departemen Pendidikan Nasional.

Suparlan, Dkk. (2016). Pendidikan Kewarganegaraan dalam konteks Indonesia. Malang: Madani.

Suparlan, H. (2015). Filsafat Pendidikan Ki Hadjar Dewantara dan Sumbangannya bagi Pendidikan Indonesia. Jurnal Filsafat. Vol.25, No.1, Hal 57-74.

Susilo, S. V. (2018). Refleksi Nilai-Nilai Pendidikan Ki Hadjar Dewantara Dalam Upayaupaya Mengembalikan Jati Diri Pendidikan Indonesia. Jurnal Cakrawala Pendas. Vol. 4, No.1. Hal 33-40.

Yuki, G. (2015). (Ed. 7). Kepemimipinan dalam Organisasi. Indeks 